\title{
Pengaruh Terapi Bermain Mewarnai Gambar terhadap Kecemasan Hospitaslisasi pada Anak Prasekolah
}

\author{
Dwi Aryani ${ }^{1}$, Nedra Wati Zaly ${ }^{2 *}$ \\ ${ }^{1}$ Mahasiswa Program Studi Sarjana Keperawatan STIKes Jayakarta \\ ${ }^{2}$ Sekolah Tinggi Ilmu Kesehatan Jayakarta \\ Emal: *nedrawati12@gmail.com
}

Submitted : 01/10/2020

Accepted: 06/01/2021

Published: 06/03/2021

\begin{abstract}
Hospitalization is a state of crisis in children, when the child is sick and hospitalized. The hospital care environment can cause fear and anxiety in the child. Play activity therapy is one of the good activities to overcome the anxiety of children who are hospitalized, so that it can accelerate the healing process of pain in children. This study aims to find out the effect of play therapy coloring pictures on anxiety due to hospitalization in preschool age children in the pavilion of Gatot Soebroto Hospital. This research applies pre-experimental method with one group pre test post test design approach. The sample of this study was 35 respondents with purpose sampling techniques. T test results obtained $p=0.000$ value if $\alpha=0.05$ then $p<\alpha$ and Ha are accepted. The results of this study showed that there is an influence of play therapy coloring pictures on the decrease in anxiety due to hospitalization in preschool-age children in the Pavilion of Gatot Soebroto Hospital in 2019. This research is expected to increase play therapy activities as one of the interventions to help reduce anxiety, especially preschool-age children who are experiencing hospitalization.
\end{abstract}

Keywords: anxiety, hospitalization, play therapy preschoolers

\begin{abstract}
Abstrak
Hospitalisasi adalah suatu keadaan krisis pada anak, saat anak sakit dan dirawat di rumah sakit. Lingkungan perawatan rumah sakit dapatmenimbulkan rasa takut dan kecemasan pada anak.Terapi aktivitas bermain merupakan salah satu kegiatan yang baik untuk mengatasi cemas anak yang dirawat di Rumah Sakit, sehingga dapat mempercepat proses penyembuhan sakit pada anak. Penelitian ini bertujuan untuk mengetahui pengaruh terapi aktivitas bermain mewarnai gambar terhadap kecemasan akibat hospitalisasi pada anak usia prasekolah di paviliun RSPAD Gatot Soebroto. Penelitian ini menerapkan metode pra-eksperiment dengan pendekatan one group pre test post test design. Sampel penelitian ini sebanyak 35 responden dengan teknik purpose sampling. Hasil uji t test diperoleh nilai $\mathrm{p}$ $=0,000$ jika $\alpha=0,05$ maka $\mathrm{p}<\alpha$ dan Ha diterima. Hasil penelitian ini menunjukkan bahwa ada pengaruh terapi aktivitas bermain mewarnai gambar terhadap penurunan kecemasan akibat hospitalisasi pada anak usia prasekolah di Paviliun RSPAD Gatot Soebroto tahun 2019.Penelitian ini diharapkan dapatmeningkatkankegiatan terapi bermain sebagai salah satu intervensi untuk membantu menurunkan kecemasan khususnya anak usia prasekolah yang mengalami hospitalisasi.
\end{abstract}

Kata kunci : anak prasekolah, hospitalisasi, kecemasan, terapi bermain 


\section{PENDAHULUAN}

Hospitalisasi adalah suatu keadaan krisis pada anak, saat anak sakit dan dirawat di rumah sakit.Keadaan ini terjadi karena anak berusaha untuk berada untuk beradaptasi dengan lingkungan asing dan baru yaitu rumah sakit, sehingga kondisi tersebut menjadi stressor baik terhadap anak maupun orangtua dan keluarga(Wong, 2009).

Lingkungan perawatan rumah sakit yang dapatmenimbulkan rasa takut dan kecemasan pada anak. Terjadinya luka pada anak akibat tindakan keperawatan merupakan penyebab utama kecemasan pada anak usia prasekolah yang mengalami hospitalisasi (Dayani, Budiarti, \& Lestari, 2015).

Data WHO (2012) menunjukkan bahwa 3-10\% anak dirawat di Amerika Serikat, baik anak usia toddler, anak prasekolah ataupun anak usia sekolah, sedangkan di Jerman sekitar 3 sampai $7 \%$ dan anak toddler dari 5-10\% anak prasekolah yang menjalani perawatan Rumah Sakit, jumlah anak menurut UNICEF yaitu anak berusia 0-14 tahun berjumlah 8,4 juta anak. Hasil survei UNICEF pada tahun 2012 persentase anak yang menjalani perawatan dirumah sakit sebesar 84\% (Unicef, 2012).

Dari hasil survei data Riset Kesehatan Dasar (RisKesDas) tahun 2013 didapatkan data bahwa anak yang menjalani rawat inap diseluruh Indonesia sebesar 2,8\% dari total jumlah anak di Indonesia.Referensi data yang di dapat dari Rumah Sakit Pusat Angkatan Darat Gatot Soebroto (RSPAD Gatot Soebroto) didapat dari register pada tahun 2018 bulan Januari sampai dengan bulan September diantaranya yaitu jumlah total berjumlah 1.445 anak yang mengalami hospitalisasi dantaranya yaitu, usia bayi $0-1$ tahun berjumlah 147 anak, usia 1-3 tahun berjumlah 300 anak, usia 3-6 tahun berjumlah 366 anak, usia 6-12 tahun 376 anak, usia 12-18 tahun berjumlah 256 anak.

Penyakit dan hospitalisasi sering menjadi krisis pertama yang harus dihadapi oleh anak(Wong, 2009). Untuk mengurangi dampak anak dari hospitalisasi yang dialami anak selama perawatan anak, maka diperlukan suatu media yang dapat mengungkapkan rasa cemas salah satunya adalah terapi bermain (Dayani, Budiarti, and Lestari, 2015).

Terapi mewarnai gambar merupakan salah satu permainan yang sesuai dengan prinsip rumah sakit dimana secara psikologis permainan ini dapat membantu anak dalam mengekspresikan perasaan cemas, takut, sedih, tertekan dan emosi (Arifin\& Udiyani, 2019).

Adapun tujuan penelitian ini adalah sebagai berikut: Mengetahui tingkat kecemasan pada anak usia prasekolah yang mengalami hospitalisasi sebelum diberikan terapi mewarnai gambar diruang paviliun anak RSPAD Gatot Soebroto. Mengetahui tingkat kecemasan pada anak usia prasekolah yang mengalami hospitalisasi sesudah diberikan terapi mewarnai gambar di ruang paviliun anak RSPAD Gatot Soebroto.Mengetahui pengaruh pemberian terapi bermain mewarnai gambar terhadap tingkat kecemasan pada ana usia prasekolah yang mengalami hospitalisasi di ruang paviliun anak RSPAD Gatot Soebroto.

Hospitalisasi merupakan pengalaman yang tidak menyenangkan dan akan memunculkan respon kecemasan pada anak. Dampak kecemasan yang bisa terjadi pada anak prasekolah seperti menarik diri, menangis, tidak mau berpisahdengan orang tua, tingkah laku protes serta lebih peka lagi dan pasif seperti menolak makan dan menolak tindakan invasif yang diberikan perawat sehingga akan memperlambat proses penyembuhan anak (Hidayat, 2012).

Untuk mengurangi dampak kecemasan akibat hospitalisasi yang dialami anak diperlukan suatu media yang dapat mengungkapkan rasacemas anak, 
salah satunya yaitu terapi bermain. Terapi bermain merupakan kegiatan untuk dapat membantu proses penyembuhan anak dan sarana dalam melanjutkan perkembangan yang optimal.

Salah satu terapi bermain yang sesuai dengan usia anak prasekolah adalah terapi bermain mewarnai gambar. Berdasarkan latar belakang tersebut, peneliti merumuskan masalah bahwa dengan terapi bermain dapat mempengaruhi penurunan kecemasan pada anak sehingga peneliti merumuskan adakah pengaruh terapi bermain mewarnai gambar terhadap kecemasan hospitalisasi anak prasekolah?

Hospitalisasi merupakan suatu keadaan kritis pada anak, saat anak sakit dan dirawat di Rumah Sakit. Keadaan ini dapat terjadi salah satunya disebabkan oleh kecemasan pada anak yang menyebabkan perubahan fisiologis dan psikologis, jika anak tidak mampu beradaptasi terhadap perubahan tersebut. Dampak jangka pendek dari kecemasan dan ketakutan yang yang tidak segera ditangani akan membuat anak melakukan penolakan terhadap tindakan perawatan dan pengobatan yang diberikan sehingga berpengaruh terhadap lamanya hari rawat, memperberat kondisi anak dan bahkan dapat menyebabkan kematian pada anak(Saputro, \&Fazrin, 2017).

Cemas adalah suatukeadaan patologik yang ditandai oleh perasaan ketakutan disertai tanda somatik pertanda sistem saraf otonomyang hiperaktif. Dibedakan dari rasa takut yang merupakan respon terhadapsuatu penyebab yang jelas (Kaplan, Saddock, \& Grabb, 2010).

Menurut Stuard \& Sundeen (2006) faktor predisposisi kecemasan timbul karena adanya perasaan sakit dan tidak adanya penerimaan terhadap kondisi yang ada, kecemasantimbul karena ketidakmampuan dari seseorang mencapai keinginan. Tingkat kecemasan ada empat yaitu: ringan, sedang, berat, dan panik (Kaplan, Saddock, \& Grabb, 2010)
Kecemasan Ringan;

Cemas yang normal yang menjadi bagian dari kehidupan sehari-hari dan menyebabkan seseorang waspada dan meningkatkan lahanpersepsinya.Cemas ini dapat memotivasi belajar danmenghasilkan kreativitas anak.Gejalanya ringan seperti gemetar, tegang, dan gelisah, takut.

Kecemasan Sedang

Kecemasan sedang memiliki gejala fisiologis seperti persepsi panjang menyempit, respon muncul secara langsung (dapat merespon terhadap perintah), masih dapat memecahkan masalah secara efektif dan merespon langsung serta perlu dukungan dan perhatian selektif dan terfokus pada rangsangan yang tidak menambah kecemasan.Kecemasan sedang secara emosional menimbulkan tingkah laku tidak sadar, mudah tersinggung, mudah lupa, banyak pertimbangan, menangis dan marah, menggunakan berbagai macam mekanisme koping untuk mengatasi kecemasan.

Kecemasan Berat

Kecemasan berat sangat mengurangi persepsi, seseorang individu cenderung untuk memusatkan pada sesuatu yang rinci dan spesifik serta tidak dapat berpikir tentang hal lain.Tanda-tanda kecemasan berat berupa perasaan terancam, ketegangan otot berlebihan, perubahan pernafasan, perubahan gastrointestinal (mual, muntah, rasa terbakar pada ulu hati, sendawa, anoreksia dan diare).

Kecemasan Panik

Tingkat panik dari suatu cemas berhubungan dengan ketakutan, dan teror.Orang yang mengalami panik tidak mampu melakukan sesuatu walaupun dengan pengarahan, karena kehilangan kendali. Ketika panik, terjadi peningkatan aktivitas motorik,menurunnya kemampuan berhubungan dengan orang lain, persepsi yang menyimpang dan kehilangan pemikiran yang rasional. Tidak dapat belajar memecah masalah, membuat keputusan dan membuat tujuan yang 
realistis, juga tidak dapat berespon terhadap perintah.

Dampak kecemasan Dampak kecemasan yang bisa terjadi pada anakprasekolah sepertimenarik diri, menangis, tidak mau berpisah dengan orang tua, tingkah laku protes serta lebih peka lagi dan pasif seperti menolak makan dan menolak tindakan invasif yang diberikan perawat sehingga akan memperlambat proses penyembuhan anak (Hidayat, 2012).

Salah satu upaya yang dapat dilakukan untuk menurunkan kecemasan adalah melalui kegiatan terapi bermain. Bermain merupakan salah satu alat komunikasi yang natural bagi anak-anak. Bermain merupakan dasar pendidikan dan aplikasi terapeutik yang membutuhkan pengembangan pada pendidikan anak usia dini (Tekin and Sezer, 2010).

Salah satu fungsi bermain adalah sebagaiterapi dimana dengan melakukan permainananak akan terlepas dari ketegangan dan stressyang dialaminya. Melalui kegiatan bermain,anak dapat mengalihkan rasa sakitnya padapermainannya (distraksi) dan relaksasi melaluikesenangannya

melakukanpermainan tersebut.

Terapi bermain dapat membuat anak-anak melepaskan perasaan marah, sedih, atau rasa cemas yang sebelumnya terasa sulit bagi anak untuk mengekspresikan perasaan tersebut. Anak kemungkinan mengalami kesulitan mengekspresikan perasaan karena intensitas trauma yang dialami, atau karena kurangnya sistem pendukung yang akan memungkinkan anak untuk mengekspresikan perasaannya. Hasil akhir dari kegiatan terapi bermain memberikan perasaan lega bagi anak (Kaduson, and Schaefer, 2006).

Mewarnai gambar merupakan suatu bentuk kegiatan kreativitas, dimana anak diajak untuk memberikan satu atau beberapa goresan warna pada suatu bentuk atau pola gambar, sehingga terciptalah sebuah kreasi seni(Olivia, 2013).

Ada banyak manfaat mewarnai gambar bagi anak, antara lain: melatih anak mengenal aneka warna dan nama-nama warna, menstimulasi daya imajinasi dan kreativitas, melatih mengenal objek yang akan diwarnai, melatih anak untuk membuat target, melatih anak mengenal garis batas, melatih keterampilan motorik halus anak sebagai salah satu sarana untuk mempersiapkan kemampuan menulis, melatih kemampuan koordinasi antar mata dan tangan. Mulai dari berbagai cara yang tepat menggenggam krayon hingga memilih warna dan menajamkan krayon sebagai terapi permainan kreatif yang merupakan metode penyuluhan kesehatan untuk merubah prilaku anak selama dirumah sakit(Olivia, 2013).

\section{METODE PENELITIAN}

Rancangan penelitian ini menggunakan praeksperimen yang bertujuan melihat pengaruh antara pemberian terapi bermain terhadap tingkat kecemasan anak usia prasekolah.Peneliti menggunakan rancangan one group pre test - pst test design. Peneliti melakukan perlakuan pada satu kelompok, sebelum diberikan perlakuan, responden di observasi terlebih dahulu, sebagai pre test. Lalu setelah perlakuan, responden di observasi kembali sebagai post test.

Metode pengumpulan data yang digunakan yaitu observasi. Observasi merupakan cara melakukan pengumpulan data penelitian untuk mencari perubahan atau hal-hal yang akan diteliti. Penelitian ini menggunakan teknik purposive sampling, dengan kriteria inklusi (1). Pasien anak usia prasekolah (3-6 tahun), (2). Anak usia prasekolah yang didampingi orang tua atau keluarga. (3). Anak usia prasekolah yang mau diajak bermain, (4). Anak usia prasekolah dengan kondisi fisik yang stabil. Penelitian ini dilakukan di ruang paviliun 
anak RSPAD Gatot Soebroto pada bulan April hingga Juni 2019.

Cara pengambilan data untuk variabel tingkat kecemasan dengan prosedur sebagai berikut:

1. Peneliti memilih responden di ruang perawatan anak, dengan mengadakan pendekatan pada calon responden, kemudian memberikan penjelasan kepada orang tua tentang tujuan, manfaat penelitian. Jika orang tua responden bersedia maka orang tuaresponden akan menandatanganilembar persetujuan responden.

2. Setelah orang tua responden menandatangani lembar persetujuan, maka peneliti meminta orang tua responden untuk mulai mengisilembaran kuesioner sebelum terapi bermain mewarnai dilakukan. Hasil pengisian ini dinilai sebagi data pre test.

3. Kemudian anak diberikan terapi bermain mewarnai sesuai standar operasional prosedur (SOP).

4. Setelah dilakukan terapi bermain mewarnai sesuai standar operasional prosedur, orang tua responden di minta kembali untuk mengisi lembaran kuesioner sebagai hasil data post test.

5. Setelah seluruh pertanyaan dijawab oleh orang tua responden secara lengkap kemudian lembaran kuisioner pretest dan posttest diberikan kepada peneliti untuk dilakukan pengecekan dan perhitungan.

Instrumen yang digunakan dalam penelitian ini adalah kuesioner yang terdiri dari 15 pertanyaan, pertanyaan berupa informasi orang tua yang benar mengenai anaknya. Nilai kuesioner respon tidak patuh diberikan nilai 1 , kadang-kadang nilai 2, sering nilai 3 , dan selalu nilai 4 . Kuesioner sudah dilakukan uji validitas dan reabilitas. Peneliti melakukan uji validitas dengan membagikan kuesioner pada 20 orang tua yang bukan termasuk responden. Hasil uji validitas semua item pertanyaaan dinyatakan valid. Sedangkan hasil uji reabilitas diketahui angka cronbach's alpha adalah sebesar $0.936(\geq 0,80)$. Hal ini menunjukkan bahwa data sudah sangat reabilitas.
Uji statistik yang digunakan disesuaikan dengan hasil uji normalitas data, apabila data berdistribusi normal, maka statistik yang digunakan adalah uji ttest. Apabila data tidak berdistribusi normal statistik yang digunakan adalah uji Mann whitney testdengan kemaknaan 95\% $(\alpha=$ $0,05)$.

\section{HASIL DAN PEMBAHASAN}

1. Karakteristik responden berdasarkan jenis kelamin dan usia

Tabel 1. Distribusi Frekuensi berdasarkan Jenis Kelamin dan Usia anak Usia Prasekolah Yang diRawat di Paviliun Anak Tahun 2019

\begin{tabular}{lll}
\hline Variabel & $\mathrm{N}$ & $\%$ \\
\hline Jenis Kelamin & & \\
- Laki-laki & 19 & 54,3 \\
- Perempuan & 16 & 25,7 \\
\hline Usia anak & & \\
\hline - 3 tahun & 5 & 14,3 \\
- 4 tahun & 12 & 34,3 \\
- 5 tahun & 10 & 28,6 \\
- 6 tahun & 8 & 22,8 \\
\hline
\end{tabular}

Berdasarkan tabel1 diatas didapatkan bahwa 54,3\% anak dengan jenis kelamin laki-laki. Dan usia 4 tahun yang paling banyak mengikuti kegiatan terapi bermain ini yakni sebanyak 34,3 $\%$.

2. Tingkat kecemasan anak sebelum dan setelah Terapi Aktivitas Mewarnai

Tabel 2. Distribusi Frekuensi Tingkat Kecemasan Anak Usia Prasekolah Sebelum dan Sesudah diberikan Terapi Aktivitas Bermain Mewarnai Gambar.

\begin{tabular}{lllll} 
Tingkat & \multicolumn{2}{l}{ Pre Test } & \multicolumn{2}{c}{ Post Test } \\
\cline { 2 - 5 } Kecemasan & $\mathrm{n}$ & $\%$ & $\mathrm{n}$ & $\%$ \\
Ringan & 0 & 0 & 7 & 20 \\
Sedang & 6 & 17,1 & 28 & 80 \\
Berat & 29 & 82,9 & 0 & 0 \\
\hline
\end{tabular}


Berdasarkan tabel 2 menunjukkan bahwa responden di paviliun anak di RSPAD hampir mengalami kecemasan berat sebanyak 29 anak (82.9 \%) sebelum diberikan terapi bermain.Sesudah diberikan terapi bermain menunjukkan sebanyak 28 anak $(80 \%)$ mengalami kecemasan sedang.

Menurut (Utami, 2014) terdapat beberapa faktor yang dapat menimbulkan stres ketika anak mengalami hospitalisasi seperti lingkungan rumah sakit, berpisah dengan orang terdekat, kehilangan kendali dan cedera tubuh dan nyeri.

Bermain dapat meningkatkan daya pikir anak untuk mendayagunakan aspek emosional, sosial serta fisiknya serta dapat meningkatkan kemampuan fisik, pengalaman, dan pengetahuan serta keseimbangan mental anak(Adriana, 2011). Terapi bermain merupakan terapi yang diberikan dan digunakan anak untuk menghadapi ketakutan, kecemasan dan mengenal lingkungan perawatan dan prosedur yang dilakukan serta staf rumah sakit yang ada(Wong, 2009).

Bermain pada anak di rumah sakit menjadi media bagi anak untuk mengekspresikan perasaan tanpa kata-kata, dimana bermain mewarnai gambar membuat seseorang secara tidak sadar telah mengekspresikan rasa sedih, tertekan, stres dan membuat kembali merasa bahagia(Aizah and Wati, 2014). Hal ini sejalan dengan penelitian yang dilakukan oleh Li, Chung, Ho, dan Kwok(2016) menekankan pentingnya terapi bermain di rumah sakit untuk memberikan perawatan yang holistik dan berkualitas dalam upaya untuk meringankan beban psikologis anakanak yang dirawat di rumah sakit.

3. Pengaruh Pemberian Terapi Aktivitas Bermain terhadap Penurunan Kecemasan Anak usia prasekolah

Hasil analisa bivariat pada penelitian ini menjelaskan ada tidaknya pengaruh terapi bermain mewarnai gambar yang diberikan petugas kesehatan terhadap kecemasan hospitalisasianak, dengan memaparkan ada tidaknya perbedaan nilai sebelum dan sesudah mendapatkan intervensi.

Tabel 3. Distribusi frekuensi Pengaruh Pemberian Terapi Bermain Terhadap PenurunanTingkat Kecemasan Pada Anak Usia Prasekolah Yang diRawat di Paviliun Anak Tahun 2019

\begin{tabular}{llll}
\hline $\begin{array}{c}\text { Tingkat } \\
\text { Kecemasan }\end{array}$ & Mean & Uji T & $\begin{array}{c}P \\
\text { value }\end{array}$ \\
\hline Pre test & 2,83 & 20,58 & 0,00 \\
Post test & 1,80 & & \\
\hline
\end{tabular}

Pada tabel 3 menunjukkan perbedaan rata-rata kecemasan sebelum dan sesudah terapi bermain. Setelah dilakukan uji t didapatkan nilai t hitung sebesar 20,58, lebih besar dibanding $t$ tabeldengan nilai $p$ 0,00 . Hal ini menunjukkan bahwa adanya pengaruh pemberian terapi bermain terhadap tingkat kecemasan anak.

Hasil penelitian ini didukung oleh beberapa penelitian lainnya diantaranya berdasarkan hasil penelitian (Arifin and Udiyani, 2019)menunjukkan bahwa ada perbedaan efektifitas terapi menggambar dan mewarnai gambar terhadap penurunan kecemasan pada anak usia pra sekolah di Rumah Sakit RSUD dr. H. Andi Abdurrahman Noor. Sejalan dengan penelitian (Suryanti, Sodikin, and Yulistiani, 2012)yang membuktikan terdapat perbedaan antara tingkat kecemasan yang dialami anak sebelum dilakukan terapi bermain (mewarnai dan origami) dan sesudah dilakukan terapi bermain (mewarnai dan origami).

Selain dapat menurunkan kecemasan, terapi bermain dapat juga sebagai upaya dalam penerapan atraumatic care sesuai dengan penelitianBreving, Ismanto, dan Onibala, (2015)yang menunjukkan adanya pengaruh penerapan atraumatic care terhadap respon kecemasan anak. Penerapan atraumatic care yang 
dilakukan pada penelitian ini adalah pemberian mainan pada responden anak sebelum dilakukan pemasangan infus dan diberikan kompres es batu.

Anak memiliki kebutuhan emosional seperti dicintai, dihargai, dan merasa aman. Pada usia prasekolah, anakanak belajar menguasai dan mengekspresikan emosi. Pada tahapan ini anak memerlukan pengalaman pengaturan emosi, seperti mengontrol dan mengarahkan ekspresi emosional serta menjaga perilaku saat munculnya emosiemosi yang kuat.

Terdapat 4 (empat) gangguan emosi pada anak yaitu; ketidakmampuan untuk menunjukkan tingkah laku yang tepat dalam situasi tertentu, ketidakmampuan untuk membangun hubngan pertemanan dengan teman sebaya, mudah merasa depresi atau cemas hanya karena alasanalasan kecil, dan memiliki gangguan gejala tertentu menghadapi masalah seperti sakit perut ketika disuruh maju ke depan kelas, takut dengan orang berkumis, dan sebagainya(Muthmainnah, 2017).

Bermain memungkinkan anak terlepas dari ketegangan dan stres yang dialami anak selama hospitalisasi(Supartini, 2012). Terapi bermain merupakan suatu proses penyembuhan dengan metode bermain yang digunakan pada anak yang mempunyai masalah emosi, terutama anak usia prasekolah dengan tujuan mengubah tingkah laku anak yang tidak sesuai menjadi tingkah laku yang diharapkan. Pelaksanaan terapi bermain sudah sesuai dengan prinsip terapi bermain bagi anak di rumah sakit yaitu permainan yang tidak boleh bertentangan dengan pengobatan yang sedang dijalankan pada anak, permainan yang tidak membutuhkan energi, singkat dan sederhana, permainan yang harus mempertimbangkan keamanan anak (Karsi, 2013 dalam Kaluas, Ismanto, and Kundre, 2015).

\section{SIMPULAN}

Penelitian ini dapat disimpulkan: Tingkat kecemasan pada anak usia prasekolah yang mengalami hospitalisasi sebelum diberikan terapi bermain mewarnai gambar di ruang paviliun anak RSPAD sebagian besar tergolong kecemasan berat yaitu sebanyak 29 anak (82.9 \%). Tingkat kecemasan pada anak usia prasekolah yang mengalami hospitalisasi sesudah diberikan terapi bermain di ruang pviliun anak di RSPAD sebagian besar tergolong kecemasan sedang 28 anak (80\%). Terdapat pengaruh pemberian terapi bermain terhadap tingkat kecemasan pada anak usia prasekolah di ruang paviliun anak di RSPAD).

\section{SARAN}

Disarankan kepada Instansi RS dapat meningkatkan pengetahuan perawat tentang pentingnya terapi bermain sebagai salah satu intervensi dalam memberikan asuhan keperawatan untuk membantu menurunkan kecemasan khususnya anak usia prasekolah yang mengalami hospitalisasi.

\section{DAFTAR PUSTAKA}

Adriana, D. (2011). Tumbuh kembang dan terapi bermain pada anak. Jakarta: Salemba Medika.

Aizah, S., \& Wati, S. E. (2014). Upaya Menurunkan Tingkat Stres Hospitalisasi Dengan Aktifitas Mewarnai Gambar pada Anak Usia 46 Tahun di Ruang Anggrek RSUD Gambiran Kediri. Ejornal Kedokteran Universitas Airlangga, 25(1), 6-10. Retrieved from http://lp2m.unpkediri.ac.id/jurnal/page s/efektor/Nomor25/Hal 6-10. Penelitian hospitalisasi Siti Aiz.pdf

Arifin, R.F. Udiyani, R. R. R. (2019). Efektifitas terapi menggambar dan mewarnai gambar terhadap kecemasan hospitalisasi usia prasekolah. Jurnal Darul Azhar, 6(1), 53-58.

Breving, RM. Ismanto, AY. Onibala, F. 
(2015). Pengaruh penerapan atraumatic care terhadap respon kecemasan anak yang mengalami hospitalisasi di RSU Pancaran Kasih GMIM Manado dan RSUP Prof. DR. R. D. Kandou Manado. EJournal Keperawatan (e-Kp), 3(2), 1-9.

Dayani, NE. Budiarti, LY. Lestari, D. (2015). Terapi bermain Clay terhadap kecemasan pada anak usia prasekolah (3-6 tahun) yang menjalani hospitalisasi di RSUD Banjarbaru. Dunia Keperawatan Jurnal Keperawatan Dan Kesehatan, 3(2), 115.

Hidayat, A. A. (2012). Pengantar ilmu keperawatan anak 1. Jakarta: Salemba Medika.

Kaduson, H.G., \& Schaefer, C. E. (2006). Short-term play therapy for children. 2nd Ed. Retrieved from https://books.google.co.id/books?hl=id $\& 1 \mathrm{r}=\& \mathrm{id}=\mathrm{w}-$

aJ5zYoAcQC\&oi=fnd $\& p g=P A 3 \& d q=$ therapy+play+interventions\&ots $=y x z a$ nMRjyh\&sig $=x 0 n j J-$

UD7wp8WyB7s9MEtw8nPy8\&redir_ $\mathrm{esc}=\mathrm{y} \# \mathrm{v}=$ onepage $\& \mathrm{q}=$ therapy play interventions $\& \mathrm{f}=$ false

Kaluas, I. Ismanto, A.Y. \& Kundre, R. M. (2015). Perbedaan terapi bermain puzzle dan bercerita terhadap kecemasan anak usia prasekolah (3-5 tahun) selama hospitalisasi di ruang anak RS TK. III R.W. Mongisidi Manado. EJournal Keperawatan (e$K p), 3(2), 1-8$.

Kaplan, HI; Saddock, BJ; Grabb, J. (2010). Sinopsis psikiatri: Ilmu pengetahuan perilaku psikiatri klinis. Tangerang: Bina Rupa Aksara.

Li, W. H. C., Chung, J. O. K., Ho, K. Y., \& Kwok, B. M. C. (2016). Play interventions to reduce anxiety and negative emotions in hospitalized children. BMC Pediatrics, 16(1), 1-9. https://doi.org/10.1186/s12887-0160570-5
Muthmainnah, -. (2017). Peranan Terapi Menggambar Sebagai Katarsis Emosi Anak. Jurnal Pendidikan Anak, 4(1), 524-529. https://doi.org/10.21831/jpa.v4i1.1233 8

Olivia, F. (2013). Gembira bermain corat coret. Jakarta: Kompas Gramedia.

Saputro, H. Fazrin, I. (2017). Anak sakit wajib bermain di Rumah Sakit: Penerapann terapi bermain anak sakit, proses, manfaat dan pelaksanaannya. Jakarta: Forum Ilmiah Kesehatan (FORIKES).

Supartini, Y. (2012). Konsep dasar keperawatan anak. Jakarta: EGC.

Suryanti,S. Sodikin,S. Yulistiani, M. (2012). Pengaruh terapi bermain mewarnai dan origami terhadap tingkat kecemasan sebagai efek hospitalisasi pada anak usia pra sekolah di RSUD dr. R. Goetheng Tarunadibrata Purbalingga. Jurnal Kesehatan Samodra Ilmu, 3(2), 71-80.

Tekin, G., \& Sezer, Ö. (2010). Applicability of play therapy in Turkish early childhood education system: Today and future. Procedia Social and Behavioral Sciences, 5, 5054.

https://doi.org/10.1016/j.sbspro.2010.0 7.049

Unicef. (2012). Progress for children a world fit for children statistical review. Retrieved from https://www.unicef.org/progressforchil dren/2007n6/files/Progress_for_Childr en_-_No._6.pdf

Utami, Y. (2014). Dampak Hospitalisasi Terhadap Perkembangan Anak. Jurnal Ilmiah WIDYA, 9(2), 9-20. Retrieved from

http://digilib.mercubuana.ac.id/manage r/t\%21@file_artikel_abstrak/Isi_Artik el_891255124583.pdf

Wong, D. (2009). Buku ajar keperawatan pediatrik. Jakarta: EGC. 